\title{
Emerging infectious diseases: prediction and detection
}

\author{
NH Ogden', P AbdelMalik², JRC Pulliam³
}

\begin{abstract}
Emerging infectious diseases (EIDs), including West Nile virus, severe acute respiratory syndrome (SARS) and Lyme disease, have had a direct effect within Canada, while many more EIDs such as Zika, chikungunya and Ebola are a threat to Canadians while travelling. Over 75\% of EIDs affecting humans are, or were originally, zoonoses (infectious diseases transmitted from animals to humans). There are two main ways by which infectious diseases can emerge: by changes in their geographical ranges and by adaptive emergence, a genetic change in a microorganism that results in it becoming capable of invading a new niche, often by jumping to a new host species such as humans. Diseases can appear to emerge simply because we become capable of detecting and diagnosing them. Management of EID events is a key role of public health globally and a considerable challenge for clinical care. Increasingly, emphasis is being placed on predicting EID occurrence to "get ahead of the curve" - that is, allowing health systems to be poised to respond to them, and public health to be ready to prevent them. Predictive models estimate where and when EIDs may occur and the levels of risk they pose. Evaluation of the internal and external drivers that trigger emergence events is increasingly considered in predicting EID events. Currently, global changes are driving increasing occurrence of EIDs, but our capacity to prevent and deal with them is also increasing. Web-based scanning and analysis methods are increasingly allowing us to detect EID outbreaks, modern genomics and bioinformatics are increasing our ability to identify their genetic and geographical origins, while developments in geomatics and earth observation will enable more real-time tracking of outbreaks. EIDs will, however, remain a key, global public health challenge in a globalized world where demographic, climatic, and other environmental changes are altering the interactions between hosts and pathogen in ways that increase spillover from animals to humans and global spread.
\end{abstract}

Suggested citation: Ogden NH, AbdelMalik P, Pulliam JRC. Emerging infectious diseases: prediction and detection. Can Commun Dis Rep. 2017;43(10):206-11. https://doi.org/10.14745/ccdr.v43i10a03

\author{
Affiliations \\ ${ }^{1}$ Public Health Risk Sciences \\ Division, National Microbiology \\ Laboratory, Public Health Agency \\ of Canada, Saint-Hyacinthe, QC \\ ${ }^{2}$ Field Service Training and \\ Response, Health Security \\ Infrastructure Branch, Public \\ Health Agency of Canada, \\ Ottawa, ON \\ ${ }^{3}$ South African Centre for \\ Epidemiological Modelling \\ and Analysis, University of \\ Stellenbosch, Western Cape, \\ South Africa
}

*Correspondence: nicholas. ogden@canada.ca

\section{Introduction}

The World Health Organization (WHO) defines an emerging infectious disease (EID) as "one that has appeared in a population for the first time, or that may have existed previously but is rapidly increasing in incidence or geographic range" (1). EIDs that have directly affected Canada include West Nile virus, severe acute respiratory syndrome (SARS) and Lyme disease, while many more EIDs such as Zika, chikungunya and Ebola have been a potential threat to Canadians travelling abroad. A particular feature of many EIDs is their capacity to spread internationally and impact global health. Consequently, the capacity to predict, identify and respond to them is a key preoccupation of public health.

Over $75 \%$ of EIDs affecting humans (2) are, or were originally, zoonoses (infectious diseases transmitted from animals to humans), particularly those maintained by wild animals. They are transmitted by various routes including via direct contact, food, drinking water, recreational water and arthropod vectors (3). Many zoonoses (like West Nile virus and Lyme disease) are only transmissible from animal reservoir hosts to humans without (under normal circumstances) human-to-human transmission.
Some zoonoses are transmissible from humans infected by animals to another human but with an efficiency of transmission too low for sustained human-to-human transmission in the absence of animal reservoir hosts (4). An example is the recently discovered Middle East respiratory syndrome (MERS) caused by a coronavirus (MERS-CoV), which is transmitted from putative bat reservoir hosts (5), via domesticated animals (camels) to humans (6). Transmission from infected people to other people in close contact (particularly health care workers) can also occur, but to date human-to-human transmission has been in the form of "stuttering chains" that eventually die out $(4,7)$. Some zoonoses are intrinsically highly transmissible from human-to-human; once they infect a human, an epidemic can occur in the human population as seen during the outbreak of Ebola in West Africa in 2013-2016 (8).

In this article, we briefly review how diseases emerge, discuss the drivers for their emergence and spread and present what advances are underway to improve the prediction and detection of EIDs. 


\section{How do infectious diseases emerge?}

Infectious diseases can appear to "emerge" because we develop the capacity to identify a new endemic pathogen and subsequently begin to detect infections in humans. Recently, a number of tick-borne pathogens, including Borrelia mayonii and Heartland virus, have been detected in North America through careful re-examination of samples from those patients who exhibited clinical manifestations consistent with an infectious disease but who tested negative for known pathogens $(9,10)$. However, there are two ways by which infectious diseases can truly emerge: by changes in their geographical range and by adaptive emergence.

\section{Emergence by changes in geographical range}

Many disease emergence events are associated with changes in the geographical footprint of pathogens or parasites. This may be due to changes in the natural geographical ranges of animal hosts of zoonoses and vectors and/or via dispersal of pathogens in infected humans, animal reservoirs or vectors. Dispersal may be long-distance-even global—via infected travellers; trade (legal and illicit) that may carry infected animals animal products or vectors; and natural animal migrations. Examples of long-distance dispersal include the introduction of SARS into Canada by infected travellers from the Far East (11); the introduction of West Nile virus into North America, likely via an infected mosquito carried in an aircraft into New York (12); and the introduction of Zika virus into the Americas from Asia via Micronesia (13). Dispersal may be more local due to local movements of infected people or due to changing geographical footprints of wild animal hosts and vectors, usually due to changing environmental conditions that render new ecosystems/ regions suitable for the invading species (see "Predicting infectious disease emergence" section below). Examples of EIDs that have emerged by local geographical spread include the recent expansion of Lyme disease into Canada due to the northward spread of the tick vector Ixodes scapularis from the United States (US) (14), and the local spread of Zika virus within south and central America (15).

\section{Adaptive emergence}

Adaptive emergence is the genetic change of a microorganism that results in a phenotype that is capable of invading a new ecosystem, particularly via jumping to a new host species, including humans (16). For example, the emergence of SARS and MERS-CoV is thought to have been facilitated by genetic changes enhancing transmissibility between different species and, perhaps, pathogenicity $(5,16)$, while a single mutation of chikungunya virus is thought to have facilitated its transmission by Aedes albopictus mosquitoes and its emergence in more temperate regions of the world (17). Both mutation and reassortment of genes from viruses that infect different animal species are considered key to the development of novel pandemic influenza virus strains such as pH1N1 (18).

\section{What are we doing about EIDs?}

Our response to EIDs comprises a range of activities from outbreak management, disease surveillance following emergence, and scanning for EID events. Increasingly, research aims to improve our capacity to predict EID outbreaks.

\section{Management of outbreaks}

The efforts to ensure local, national and international capacity to respond to infectious disease outbreaks, including EIDs, are beyond the scope of this review. The capacity to respond has underpinned the creation and/or design of many international (e.g., WHO) and national (e.g., Public Health Agency of Canada) public health organizations and the development of management plans for local and pandemic infectious diseases (19). To further facilitate the detection, communication and management of health threats, the international community agreed to the International Health Regulations. This legally binding instrument came into force in June 2007 with the aim of helping "...the international community prevent and respond to acute public health risks that have the potential to cross borders and threaten people worldwide" (20). How this works is described next.

\section{Surveillance for EID events}

Surveillance for EIDs is an ongoing public health activity around the world and takes many forms. As a core capacity requirement of the International Health Regulations, all WHO member states are obligated to have the capacity for both indicator- and event-based surveillance. Member states are also required to report "unusual or unexpected" events (human cases, contaminated produce or infected vectors) to $\mathrm{WHO}$ in a timely manner (20). Several types of and approaches to surveillance have been implemented over the years to help identify EIDs, and development efforts in this area continue. For example, the Global Early Warning System (GLEWS) is a warning system for health threats and emerging risks at the human-animal-ecosystems interface that recognizes the zoonotic nature of many EIDs (21). This warning system is run jointly by Food and Agriculture Organization (FAO), World Organisation for Animal Health (OIE) and WHO. A number of "passive" surveillance programs that operate internationally, such as the GeoSentinel Surveillance Network, an international network of voluntarily participating medical clinics (22) and laboratory-based surveillance (23), use more traditional indicator-based approaches. Changes in technology and the availability of data have also led to the development of event-based surveillance systems, many of which scrutinize publicly available content on the Web in search of valid signals of potential emerging threats. Examples include the Program for Monitoring Emerging Diseases (ProMed) (24), HealthMap (25) and MediSys (26). One of the earliest of these is Canada's Global Public Health Intelligence Network (GPHIN), currently maintained and operated by the Public Health Agency of Canada. GPHIN is particularly active in EID surveillance through its ongoing technical development and team of multilingual and multidisciplinary human analysts (27).

\section{Predicting infectious disease emergence}

Emphasis is being increasingly placed on predicting occurrence of EIDs. The idea is to "get ahead of the curve" so that public health actors can be poised to respond to them, or even prevent them. Assessing risk involves focusing on a number of key criteria for the level of threat that a pathogen or event poses and considering the sensitivity of pathogens to internal and 
external drivers that may trigger emergence. The key criteria include the pathogenicity of the micro-organism (i.e., the severity of the disease it causes), the potential for the pathogen to spread locally or internationally and become established in a new environment, as well as our existing capacity to control it. These different criteria can be synthesized using multi-criteria decision analysis (MCDA) in order to decide whether to act or for purposes of prioritization (28). Studies, both anticipatory and in response to ongoing EID events, are used to quantify these criteria. Examples include assessment of the capacity for international spread of infections (29) and the suitability of local environments for their invasion (30).

Assessments of risk of disease emergence that are even more anticipatory in nature involve understanding the impact of external drivers. Examples include assessment of effects of climate change and extreme weather events as actual or potential future drivers of emergence of climate-sensitive diseases such Lyme disease in Canada (31) and West Nile virus in the US (32). Other external drivers under study include levels of biodiversity; changes in biodiversity and in agriculture and land use (which may drive emergence of zoonoses as threats for the human population) $(3,33,34)$; and social changes induced by, for example, conflict that may enhance disease emergence or re-emergence by impacting public health programs (35) or by increasing international spread (36).

Another approach to getting even more "upstream" in predicting EID events is identifying animal or pathogen traits that increase the potential of microorganisms to emerge as human pathogens in terms of their capacity to spill over from animals to humans and then be transmissible from human to human (37). In general, viruses are more likely to emerge as human pathogens than other disease-causing microorganisms, as are microorganisms that are host generalists; that is, they can already infect a range of different animal species (37-40). Characteristics of the viral genome may determine the potential of viruses to emerge and spillover into humans (41). Some host species such as bats and rodents also have a particularly high potential to be reservoirs of pathogens that can spill over and emerge into humans $(40,42)$.

\section{EIDs and public health in the future}

EIDs will continue to be at the forefront of global challenges to public health. Increasing climate, biodiversity, social and land use changes, combined with a world increasingly connected by travel and trade, mean that opportunities for pathogens to emerge in animals, spillover into humans and spread rapidly and globally are increasing. Public health will need to continue to focus on three elements:

- capacity and preparedness for EID outbreak management;

- surveillance for EID events; and

- upstream assessment of the risk of infectious disease emergence.

Currently, the risks of EIDs are increasing, but so is our technological capacity to deal with them. The development of modern genomics and bioinformatics is increasing our ability to detect EID outbreaks, locate their sources (43), and identify genetic changes that can be predicted to drive emergence (16).
Technologies to capture EID events by web-based scanning and analysis for signals in social media are increasing (44). At the same time, developments in the field of earth observation (by satellites) are increasing the spatio-temporal precision of the data, and their capacity to identify changes in climate, weather, habitats and socioeconomics that may drive disease emergence (45). Increasingly then, the focus is shifting to surveillance for changes in drivers of EIDs, rather than the EIDs themselves. Thus the potential to respond preventatively to EIDs is becoming a reality.

There is a growing recognition that EIDs are equivalent to those invasive species that may be important to conservation biology and natural resource management (46). Therefore, a "One Health" approach that employs knowledge of the interconnectivity of animal, environmental and human health enhances risk assessments, predictive modelling and detection of EIDs (47). Ultimately, both indicator-based and event-based surveillance fall along a surveillance continuum, providing different but valuable data for analysis, interpretation and action. Efforts to link the different approaches into comprehensive systems that capitalize on available historical and contextual data would further strengthen the ability to detect, prepare for and respond to EIDs.

\section{Conclusion}

We continue to make great strides in our capacity to predict, detect, prepare for and manage EIDs. However, EIDs will remain a key, global public health challenge in a world where demographic, climatic and other environmental changes, including globalization, are enhancing the emergence of new pathogens, their spillover from animals to humans and their global spread.

\section{Authors' statement}

NHO, JRCP - Conceptualization; NHO, PA and JCRP, Writing original draft

\section{Conflict of interest}

None.

\section{References}

1. World Health Organization. Health topics: Emerging diseases. Geneva: World Health Organization. http://www. who.int/topics/emerging_diseases/en/ [Accessed 2017 Aug 30].

2. Woolhouse ME, Gowtage-Sequeria S. Host range and emerging and reemerging pathogens. Emerg Infect Dis. 2005;11:1842-7. DOl (http://dx.doi.org/10.3201/ eid1112.050997). PubMed (https://www.ncbi.nlm.nih. gov/entrez/query.fcgi?cmd=Retrieve $\& \mathrm{db}=$ PubMed\&lis t_uids=16485468\&dopt=Abstract). 
3. Jones KE, Patel NG, Levy MA, Storeygard A, Balk D, Gittleman JL, Dobson AP, Hudson PJ, Grenfell BT. Global trends in emerging infectious diseases. Nature 2008;451:990-3. DOI (http://dx.doi.org/10.1038/ nature06536). PubMed (https://www.ncbi.nlm.nih.gov/ pubmed/18288193?dopt=Abstract)

4. Lloyd-Smith JO, George D, Pepin KM, Pitzer VE, Pulliam $\mathrm{JR}$, et al. Epidemic dynamics at the human-animal interface. Science. 2009;326:1362-7. DOI (http://dx.doi.org/10.1126/ science.1177345). PubMed (https://www.ncbi.nlm.nih. gov/entrez/query.fcgi?cmd=Retrieve\&db=PubMed\&lis t_uids=19965751\&dopt=Abstract).

5. Wang $Q$, Qi J, Yuan $Y, X$ Xan $Y$, Han $P$, Wan Y, Ji W, Li Y, Wu Y, Wang J, Iwamoto A, Woo PC, Yuen KY, Yan J, Lu G, Gao GF. Bat origins of MERS-CoV supported by bat coronavirus HKU4 usage of human receptor CD26. Cell Host Microbe. 2014;16:328-37. DOI (http://dx.doi.org/10.1016/j. chom.2014.08.009). PubMed (https://www.ncbi.nlm.nih. gov/entrez/query.fcgi?cmd=Retrieve\&db=PubMed\&lis t_uids=25211075\&dopt=Abstract).

6. Haagmans BL, Al Dhahiry SH, Reusken CB, Raj VS, Galiano M, Myers R, Godeke GJ, Jonges M, Farag E, Diab A, Ghobashy H, Alhajri F, Al-Thani M, Al-Marri SA, Al Romaihi $\mathrm{HE}$, Al Khal A, Bermingham A, Osterhaus AD, AlHajri MM, Koopmans MP. Middle East respiratory syndrome coronavirus in dromedary camels: an outbreak investigation. Lancet Infect Dis. 2014;14:140-5. DOI (http://dx.doi.org/10.1016/ S1473-3099(13)70690-X). PubMed (https://www.ncbi.nlm. nih.gov/entrez/query.fcgi?cmd=Retrieve $\& d b=$ PubMed\&li st_uids=24355866\&dopt=Abstract).

7. WHO MERS-CoV Research Group. State of knowledge and data gaps of Middle East respiratory syndrome coronavirus (MERS-CoV) in humans. PLoS Curr. 2013;5. PubMed (https:// www.ncbi.nlm.nih.gov/entrez/query.fcgi?cmd=Retrieve\&db= PubMed\&list_uids=24270606\&dopt=Abstract).

8. Coltart CE, Lindsey B, Ghinai I, Johnson AM, Heymann DL. The Ebola outbreak, 2013-2016: old lessons for new epidemics. Philos Trans R Soc Lond B Biol Sci. 2017;372: 20160297. DOI (http://dx.doi.org/10.1098/ rstb.2016.0297). PubMed (https://www.ncbi.nlm.nih. gov/entrez/query.fcgi?cmd=Retrieve \&db=PubMed\&lis t_uids=28396469\&dopt=Abstract).

9. McMullan LK, Folk SM, Kelly AJ, MacNeil A, Goldsmith CS, Metcalfe MG, Batten BC, Albariño CG, Zaki SR, Rollin PE, Nicholson WL, Nichol ST. A new phlebovirus associated with severe febrile illness in Missouri. N Engl J Med. 2012;367:834-41. DOI (http://dx.doi.org/10.1056/ NEJMoa1203378). PubMed (https://www.ncbi.nlm.nih. gov/entrez/query.fcgi?cmd=Retrieve\&db=PubMed\&lis t_uids=22931317\&dopt=Abstract).

10. Pritt BS, Mead PS, Johnson DK, Neitzel DF, RespicioKingry LB, Davis JP, Schiffman E, Sloan LM, Schriefer ME, Replogle AJ, Paskewitz SM, Ray JA, Bjork J, Steward CR, Deedon A, Lee X, Kingry LC, Miller TK, Feist MA, Theel ES, Patel R, Irish CL, Petersen JM. Identification of a novel pathogenic Borrelia species causing Lyme borreliosis with unusually high spirochaetaemia: a descriptive study. Lancet Infect Dis. 2016;16:556-64. DOI (http://dx.doi.org/10.1016/ S1473-3099(15)00464-8). PubMed (https://www.ncbi.nlm.
nih.gov/entrez/query.fcgi?cmd=Retrieve \&db=PubMed\&li st_uids=26856777\&dopt=Abstract).

11. Ma T, Heywood A, Maclntyre CR. Chinese travellers visiting friends and relatives-a review of infectious risks. Travel Med Infect Dis. 2015;13:285-94. DOI (http://dx.doi.org/10.1016/j. tmaid.2015.05.004). PubMed (https://www.ncbi.nlm.nih. gov/entrez/query.fcgi?cmd=Retrieve $\& d b=$ PubMed\&lis t_uids=26026478\&dopt=Abstract).

12. Lanciotti RS, Roehrig JT, Deubel V, Smith J, Parker M, Steele K, Crise B, Volpe KE, Crabtree MB, Scherret JH, Hall RA, MacKenzie JS, Cropp CB, Panigrahy B, Ostlund E, Schmitt B, Malkinson M, Banet C, Weissman J, Komar N, Savage HM, Stone W, McNamara T, Gubler DJ. Crise B, Volpe KE, Crabtree MB, Scherret JH, Hall RA, MacKenzie JS, Cropp CB, Panigrahy B, Ostlund E, Schmitt B, Malkinson M, Banet C, Weissman J, Komar N, Savage HM, Stone W, McNamara T, Gubler DJ. Origin of the West Nile virus responsible for an outbreak of encephalitis in the Northeastern United States. Science. 1999;286:2333-7. DOI (http://dx.doi.org/10.1126/ science.286.5448.2333). PubMed (https://www.ncbi.nlm. nih.gov/entrez/query.fcgi?cmd=Retrieve $\& d b=$ PubMed \&li st_uids=10600742\&dopt=Abstract).

13. Baud D, Gubler DJ, Schaub B, Lanteri MC, Musso D. An update on Zika virus infection. Lancet. 2017;S01406736:31450-2. PubMed (https://www.ncbi.nlm.nih.gov/ entrez/query.fcgi?cmd=Retrieve $\& d b=$ PubMed\&list_ uids=28647173\&dopt=Abstract).

14. Ogden NH, Radojevic M, Wu X, Duvvuri VR, Leighton, PA Wu J. Estimated effects of projected climate change on the basic reproductive number of the tick vector of Lyme disease Ixodes scapularis. Environ Health Perspect. 2014;122:631-8. PubMed (https://www.ncbi.nlm.nih. gov/entrez/query.fcgi?cmd=Retrieve $\& \mathrm{db}=$ PubMed\&lis t_uids=24627295\&dopt=Abstract)

15. Anderson KB, Thomas SJ, Endy TP. The emergence of Zika virus: A narrative review. Ann Intern Med. 2016;165:175-83. DOI (http://dx.doi.org/10.7326/M16-0617). PubMed (https:// www.ncbi.nlm.nih.gov/entrez/query.fcgi?cmd=Retrieve\&db= PubMed\&list_uids=27135717\&dopt=Abstract).

16. Pepin KM, Lass S, Pulliam JR, Read AF, Lloyd-Smith JO. Identifying genetic markers of adaptation for surveillance of viral host jumps. Nat Rev Microbiol. 2010;8:802-13. DOI (http://dx.doi.org/10.1038/nrmicro2440). PubMed (https:// www.ncbi.nlm.nih.gov/entrez/query.fcgi?cmd=Retrieve\&db= PubMed\&list_uids=20938453\&dopt=Abstract).

17. Tsetsarkin KA, Vanlandingham DL, McGee CE, Higgs $\mathrm{S}$. A single mutation in chikungunya virus affects vector specificity and epidemic potential. PLoS Pathog. 2007;3(12):e201. DOI (http://dx.doi.org/10.1371/journal. ppat.0030201). PubMed (https://www.ncbi.nlm.nih.gov/ entrez/query.fcgi?cmd=Retrieve\&db=PubMed\&list_ uids $=18069894 \&$ dopt $=$ Abstract).

18. Guan Y, Vijaykrishna D, Bahl J, Zhu H, Wang J, Smith GJ. The emergence of pandemic influenza viruses. Protein Cell. 2010;1:9-13. DOI (http://dx.doi.org/10.1007/ s13238-010-0008-z). PubMed (https://www.ncbi.nlm.nih. gov/entrez/query.fcgi?cmd=Retrieve\&db=PubMed\&lis t_uids=21203993\&dopt=Abstract). 
19. World Health Organization. Emergency preparedness, response. Geneva: World Health Organization. http://www. who.int/csr/en/ [Accessed 2017 Aug 30].

20. World Health Organization. Health topics; International health regulations (IHR). Geneva: World Health Organization. http://www.who.int/topics/international_health_regulations/ en/ [Accessed 2017 Aug 30].

21. GLEWS+: Objectives. Rome: Food and Agriculture Organization. Joint publication with the World Organization for Animal Health (OIE) and the World Health Organization. http://www.glews.net/?page_id=34

22. Torresi J, Leder K. Defining infections in international travellers through the GeoSentinel surveillance network. Nat Rev Microbiol. 2009;7(12):895-901. PubMed (https://www. ncbi.nlm.nih.gov/entrez/query.fcgi?cmd=Retrieve\&db=PubM ed\&list_uids=19881521\&dopt=Abstract).

23. CDC. Emerging Infections Programs: About the Emerging Infections Programs. Atlanta: CDC Division of Preparedness and Emerging Infections. https://www.cdc.gov/ncezid/dpei/ eip/index.html [Accessed 2017 Aug 30.]

24. ProMed. About ProMED-mail. Brookline (MA): International Society for Infectious Diseases. https://www.promedmail.org/ aboutus/ [accessed 2017 Aug 30].

25. Computational Epidemiology Group. HealthMap: [ ] alerts for Alerts from past week. Boston (MA): Boston Children's Hospital. http://www.healthmap.org/ [Accessed 2017 Aug 30].

26. DG Joint Research Centre. MediSys: Most active topics. European Commission. http://medisys.newsbrief.eu/medisys/ homeedition/en/home.html [Accessed 2017 Aug 30].

27. Dion M, AbdelMalik P, Mawudeku A. Big data and the Global Public Health Intelligence Network (GPHIN). Can Commun Dis Rep. 2015;41(9):209-14. https://www.canada. ca/en/public-health/services/reports-publications/canadacommunicable-disease-report-ccdr/monthly-issue/2015-41/ ccdr-volume-41-9-september-3-2015-data/ccdr-volume-41-9september-3-2015-data-1.html

28. Hongoh V, Michel P, Gosselin P, Samoura K, Ravel A, Campagna C, Cissé HD, Waaub JP. Multi-stakeholder decision aid for improved prioritization of the public health impact of climate sensitive infectious diseases. Int J Environ Res Public Health. 2016;13:419. DOI (http://dx.doi. org/10.3390/ijerph13040419). PubMed (https://www.ncbi. nlm.nih.gov/entrez/query.fcgi?cmd=Retrieve\&db=PubMed\&l ist_uids=27077875\&dopt=Abstract).

29. Johansson MA, Powers AM, Pesik N, Cohen NJ, Staples JE. Nowcasting the spread of Chikungunya virus in the Americas. PLoS One. 2014;9:e104915. DOI (http://dx.doi.org/10.1371/ journal.pone.0104915). PubMed (https://www.ncbi.nlm. nih.gov/entrez/query.fcgi?cmd=Retrieve \&db=PubMed\&li st_uids=25111394\&dopt=Abstract).

30. Ng V, Fazil A, Gachon P, Deuymes G, Radojević M, Mascarenhas M, Garasia S, Johansson MA, Ogden $\mathrm{NH}$. Assessment of the probability of autochthonous transmission of Chikungunya virus in Canada under recent and projected climate change. Environ Health Perspect. 2017;125(6):067001. DOI (http://dx.doi.org/10.1289/ EHP669). PubMed (https://www.ncbi.nlm.nih.gov/
entrez/query.fcgi?cmd=Retrieve\&db=PubMed\&list_ uids $=28731409 \&$ dopt=Abstract).

31. Ebi KL, Ogden NH, Semenza JC, Woodward A (2017) Detecting and attributing health burdens to climate change. Environ Health Perspect. 2017;125(8):085004. DOI (http:// dx.doi.org/10.1289/EHP1509). PubMed (https://www.ncbi. $\mathrm{nlm}$.nih.gov/entrez/query.fcgi?cmd=Retrieve\&db=PubMed\&l ist_uids=28796635\&dopt=Abstract).

32. Chung WM, Buseman CM, Joyner SN, Hughes SM, Fomby TB, Luby JP, Haley RW. The 2012 West Nile encephalitis epidemic in Dallas, Texas. JAMA. 2013;310:297-307. DOI (http://dx.doi.org/10.1001/jama.2013.8267). PubMed (https://www.ncbi.nlm.nih.gov/entrez/query.fcgi?cmd=Retrie ve\&db=PubMed\&list_uids=23860988\&dopt=Abstract)

33. Pulliam JR, Epstein JH, Dushoff J, Rahman SA, Bunning $M$, Jamaluddin AA, Hyatt AD, Field HE, Dobson AP, Daszak P; Henipavirus Ecology Research Group (HERG). Agricultural intensification, priming for persistence and the emergence of Nipah virus: a lethal bat-borne zoonosis. J R Soc Interface. 2012;9:89-101. DOI (http://dx.doi. org/10.1098/rsif.2011.0223). PubMed (https://www.ncbi.nlm. nih.gov/entrez/query.fcgi?cmd=Retrieve \&db=PubMed\&li st_uids $=21632614 \& d o p t=$ Abstract).

34. McFarlane RA, Sleigh AC, McMichael AJ. Land-use change and emerging infectious disease on an island continent. Int J Environ Res Public Health. 2013;10:2699-719. DOI (http:// dx.doi.org/10.3390/ijerph10072699). PubMed (https://www. ncbi.nlm.nih.gov/entrez/query.fcgi?cmd=Retrieve\&db=PubM ed\&list_uids=23812027\&dopt=Abstract).

35. Semenza JC, Lindgren E, Balkanyi L, Espinosa L, Almqvist MS, Penttinen P, Rocklöv J. Determinants and Drivers of Infectious Disease Threat Events in Europe. Emerg Infect Dis. 2016;22:581-9. DOI (http://dx.doi.org/10.3201/ eid2204.151073). PubMed (https://www.ncbi.nlm.nih. gov/entrez/query.fcgi?cmd=Retrieve\&db=PubMed\&lis t_uids=26982104\&dopt=Abstract).

36. Ciervo A, Mancini F, di Bernardo F, Giammanco A, Vitale G, Dones P, Fasciana T, Quartaro P, Mazzola G, Rezza G. Louseborne relapsing fever in young migrants, Sicily, Italy, July-September 2015. Emerg Infect Dis. 2016;22:152-3. DOI (http://dx.doi.org/10.3201/eid2201.151580). PubMed (https://www.ncbi.nlm.nih.gov/entrez/query.fcgi?cmd=Retrie ve\&db=PubMed\&list_uids=26690334\&dopt=Abstract).

37. Plowright RK, Parrish CR, McCallum H, Hudson PJ, Ko Al, Graham AL, Lloyd-Smith JO. Pathways to zoonotic spillover. Nat. Rev. Microbiol. 2017;15(8):502-10. DOI (http://dx.doi. org/10.1038/nrmicro.2017.45). PubMed (https://www.ncbi. $\mathrm{nlm}$.nih.gov/entrez/query.fcgi?cmd=Retrieve\&db=PubMed\&l ist_uids=28555073\&dopt=Abstract).

38. Pulliam JRC. Viral host jumps: moving toward a predictive framework. EcoHealth. 2008;5:80-91. DOI (http://dx.doi. org/10.1007/s10393-007-0149-6). PubMed (https://www. ncbi.nlm.nih.gov/entrez/query.fcgi?cmd=Retrieve\&db=PubM ed\&list_uids=18648800\&dopt=Abstract).

39. Woolhouse ME, Brierley L, McCaffery C, Lycett S. Assessing the epidemic potential of RNA and DNA viruses. Emerg Infect Dis. 2016;22:2037-44. DOI (http://dx.doi.org/10.3201/ eid2212.160123). PubMed (https://www.ncbi.nlm.nih. 
gov/entrez/query.fcgi?cmd=Retrieve\&db=PubMed\&lis t_uids $=27869592 \&$ dopt $=$ Abstract)

40. Olival, KJ, Hosseini PR, Zambrana-Torrelio C, Ross N, Bogich TL, Daszak P. Host and viral traits predict zoonotic spillover from mammals. Nature 2017;546:646-50. DOI (http://dx.doi. org/10.1038/nature22975). PubMed (https://www.ncbi.nlm. nih.gov/entrez/query.fcgi?cmd=Retrieve\&db=PubMed\&li st_uids=28636590\&dopt=Abstract).

41. Geoghegan JL, Senior AM, Di Giallonardo F, Holmes EC. Virological factors that increase the transmissibility of emerging human viruses. Proc Natl Acad Sci U S A. 2016;113:4170-5. DOI (http://dx.doi.org/10.1073/ pnas.1521582113). PubMed (https://www.ncbi.nlm.nih. gov/entrez/query.fcgi?cmd=Retrieve \&db=PubMed\&lis t_uids=27001840\&dopt=Abstract).

42. Han BA, Schmidt JP, Bowden SE, Drake JM. Rodent reservoirs of future zoonotic diseases. Proc Natl Acad Sci U S A 2015;112:7039-44. DOI (http://dx.doi.org/10.1073/ pnas.1501598112). PubMed (https://www.ncbi.nlm.nih. gov/entrez/query.fcgi?cmd=Retrieve\&db=PubMed\&lis t_uids $=26038558 \&$ dopt $=$ Abstract).

43. Gilmour MW, Graham M, Reimer A, Van Domselaar G. Public health genomics and the new molecular epidemiology of bacterial pathogens. Public Health Genomics 2013;16:25-30. DOI (http://dx.doi. org/10.1159/000342709). PubMed (https://www.ncbi.nlm. nih.gov/entrez/query.fcgi?cmd=Retrieve \&db=PubMed\&li st_uids=23548714\&dopt=Abstract).
44. Quade P, Nsoesie EO. A platform for crowdsourced foodborne illness surveillance: description of users and reports. JMIR Public Health Surveill. 2017;3(3):e42. DOI (http://dx.doi.org/10.2196/ publichealth.7076). PubMed (https://www.ncbi.nlm.nih. gov/entrez/query.fcgi?cmd=Retrieve\&db=PubMed\&lis t_uids=28679492\&dopt=Abstract).

45. Brazeau S, Aubé G, Turgeon P, Kotchi S-O, Michel P. Tele-epidemiology: advancing the application of earth observation to public health issues in Canada. New York: Earthzine; 2014. https://earthzine.org/2014/05/02/ tele-epidemiology-advancing-the-application-of-earthobservation-to-public-health-issues-in-canada/

46. Dunn AM, Hatcher MJ. Parasites and biological invasions: parallels, interactions, and control. Trends Parasitol. 2015;31:189-99. DOI (http://dx.doi.org/10.1016/j. pt.2014.12.003). PubMed (https://www.ncbi.nlm.nih. gov/entrez/query.fcgi?cmd=Retrieve\&db=PubMed\&lis t_uids $=25613560 \&$ dopt=Abstract).

47. Woolhouse M. How to make predictions about future infectious disease risks. Philos Trans $\mathrm{R}$ Soc Lond B Biol Sci. 2011;366:2045-54. DOI (http://dx.doi.org/10.1098/ rstb.2010.0387). PubMed (https://www.ncbi.nlm.nih. gov/entrez/query.fcgi?cmd=Retrieve\&db=PubMed\&lis t_uids=21624924\&dopt=Abstract).

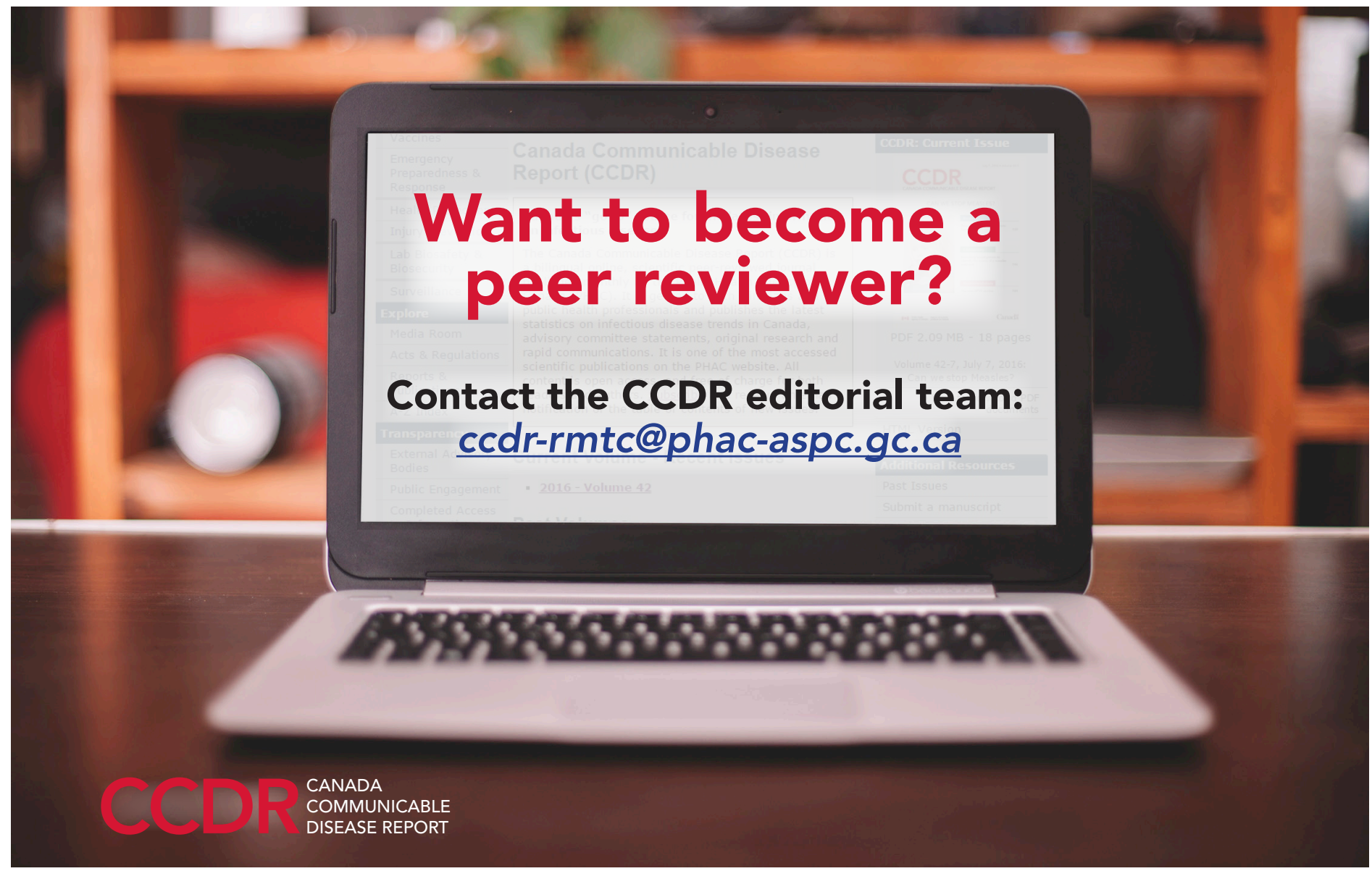

